Ann. Biol. anim. Bioch. Biophys., 1979, 19 (5), 1589-1598.

\title{
Variable development of superovulated bovine embryos between day 6 and day 12
}

par J. P. RENARD, Y. HEYMAN

Station centrale de Physiologie animale, I. N. R. A. 78350, Jouy-en-Josas, France.

Summary. The relations between the morphological aspect of superovulated embryos at a given day of recovery and their viability in vitro were studied in order to compose a test for estimating embryo quality. The observation of 994 embryos produced by 100 donors showed that at each day of recovery, from $D 6$ to $D 10$, the embryos were distributed into at least four classes according to morphological aspect. At D 11 and D 12 more than 95 p. 100 of them were divided into only two classes : abnormal and hatched blastocysts. When they were in the zona pellucida on the day of recovery, 60 p. 100 or more of the apparently normal embryos hatched after culture in vitro. $26 \mathrm{p} .100$ or less hatched in vitro when development was apparently retarded, and none of those having an abnormal aspect, according to our criteria, hatched. When they were already hatched from the zona pellucida at recovery, 80 p. 100 of the embryos showed an increase in size after $24 \mathrm{hrs}$. of culture in vitro. The percentage of normal embryos decreased from $D 6$ to $D 7$, and then remained stable until at least $D 10$. The percentage of retarded embryos increased from D 6 to $D 7$ and then decreased. A few retarded embryos were visible at days 11 and 12 . The percentage of degenerate embryos increased from $D 7$ to $D 8$ and remained stable afterwards. The proportion of donors with more than 50 p. 100 of degenerate embryos increased from D 6 to D 12. The relation with development in vivo after transplantation has been discussed.

\section{Introduction.}

For a given day of recovery, the embryos produced after superovulation of the cow ovary have different morphological aspects (Betteridge, 1977). To these differences in morphological aspect correspond differences in viability in vivo after transfer (Shea et al., 1976 ; Eldsen, Nelson and Seidel, 1978). In this study, we tried to assess the viability of embryos, recovered between days 6 and 12, by their ability to evolve in vitro after 24 to $96 \mathrm{hrs}$. in culture.

\section{Material and methods.}

110 Charolais heifers 24 to 30 months old were treated as donors between July 1976 and May 1977.

Superovulation. - All the animals were examined twice daily to detect estrus. The perfectly cycling heifers ( 2 consecutive cycles of normal length) were synchronized 
in groups of 3 or 4 donors by an intramuscular injection of $500 \mu \mathrm{g}$ of a prostaglandin analog $(\mathrm{ICl} 80996)$ between days 6 and 13 of the cycle. Ten days after the induced estrus, they were given an intramuscular injection of 2.100 IU of PMSG (Searle, lot V6J). Luteolysis was induced by $500 \mu \mathrm{g}$ of a prostaglandin analog injected $48 \mathrm{hrs}$. after the PMSG. The cows were then inseminated with the frozen sperm twice, at 56 and at $72 \mathrm{hrs}$., after the prostaglandin injection.

Embryo recovery. - The embryos were recovered after slaughter of the donors between days 6 and 12 (day $0=$ day of heat). The genital tract was taken and each uterine horn was perfused at $25^{\circ} \mathrm{C}$ with $60 \mathrm{ml}$ of a phosphate buffered saline solution (PBS, Whittingham, 1971).

Quantitative ovarian response to the superovulation treatment was assessed using the following criteria : number of ovulations estimated by the number of corpora lutea and number of anovulated follicles having a diameter $>5 \mathrm{~mm}$.

The embryos were located with a binocular lens and then carefully examined at $\times 60$ enlargement.

Morphological classification of embryos. - Three criteria were used to characterize the morphological aspect of embryos : (i) the possibility of counting the blastomeres, (ii) the presence or absence of a cavity (blastocoele), (iii) the presence or absence of the zona pellucida. They were then divided into 6 classes :

a) Embryos with no apparent structure. The embryo inside the zona pellucida, which was frequently deformed, was either in fragments with several visible blastomeres of unequal size, or was very dark and contracted with no discernable structure.

b) embryos at the 8 to 12-cell stage. These embryos had well individualized blastomeres which could be easily counted.

c) Embryos at the morula stage. The blastomeres were visible under the spherical zona pellucida, but often appeared to be superposed in a given plane. They could not be counted exactly, but numbered about 30 .

d) Embryos at the early blastocyst stage. The cellular limits were no longer visible. The embryo had a compact aspect in the zona pellucida. The blastocoele cavity was not clearly visible.

e) Embryos at the blastocyst stage. The blastocoele cavity was visible. The embryonic disk consisted of a darker cellular mass of variable size, but quite distinct from the trophoblast which was clear and attached to the zona pellucida.

f) Embryos hatched from the zona pellucida. The size of these embryos varied from 200 to $1000 \mu$. They were spheric or beginning to elongate.

Assessment of embryonic viability by in vitro culture. - For a given day of recovery and after classification of the embryos according to the morphological criteria described above, a sample of the recovered embryos was cultivated in vitro to assess embryonic viability; the in vitro culture technique used was that of Renard et al. (1976).

For embryos in the zona pellucida before culture, the criferion of viability used was the ability of the embryos to hatch from the zona pellucida in vitro. For blastocysts hatched from the zona pellucida before culture, the viability criterion used was an 
increase in the size of the blastocyst after 24 hrs. of culture (Renard ef al., 1978). The results of culture in vitro were compared with the morphological aspect of the embryos for each recovery day.

\section{Results.}

1. Quantitative ovarian response to superovulation treatment. - 91 p. 100 of the treated animals had a response higher than or equal to 1 ovulation. The mean number of ovulations was $13.03 \pm 1.8$. Ten animals out of $110(9$ p. 100) were not stimulated or did not ovulate.

Variability of the ovarian response to the same dose of PMSG on day 10 of the cycle was high. This variability is shown in figure 1 which represents donor distribution according to the number of ovulations. About $1 / 3$ of the treated donors ( 37 p. 100 produced less than 10 ovulations, $1 / 3$ (34 p. 100) presented 10 to 15 ovulations and 1/3 (28 p. 100) had more than 15 ovulations (maximum of 38 ovulations). At slaughter, $7.2 \pm 1.06$ anovulated follicles having a diameter $>5 \mathrm{~mm}$ were counted. The number of follicles was unrelated to the number of corpora lutea $(r=40)$.

2. Rate of embryonic recovery. - From 100 donors having ovulated after the treatment, we recovered 76.2 p. 100 of the embryos $(n=994)$, or a mean of $9.94 \pm 1.54$ embryos/donor.

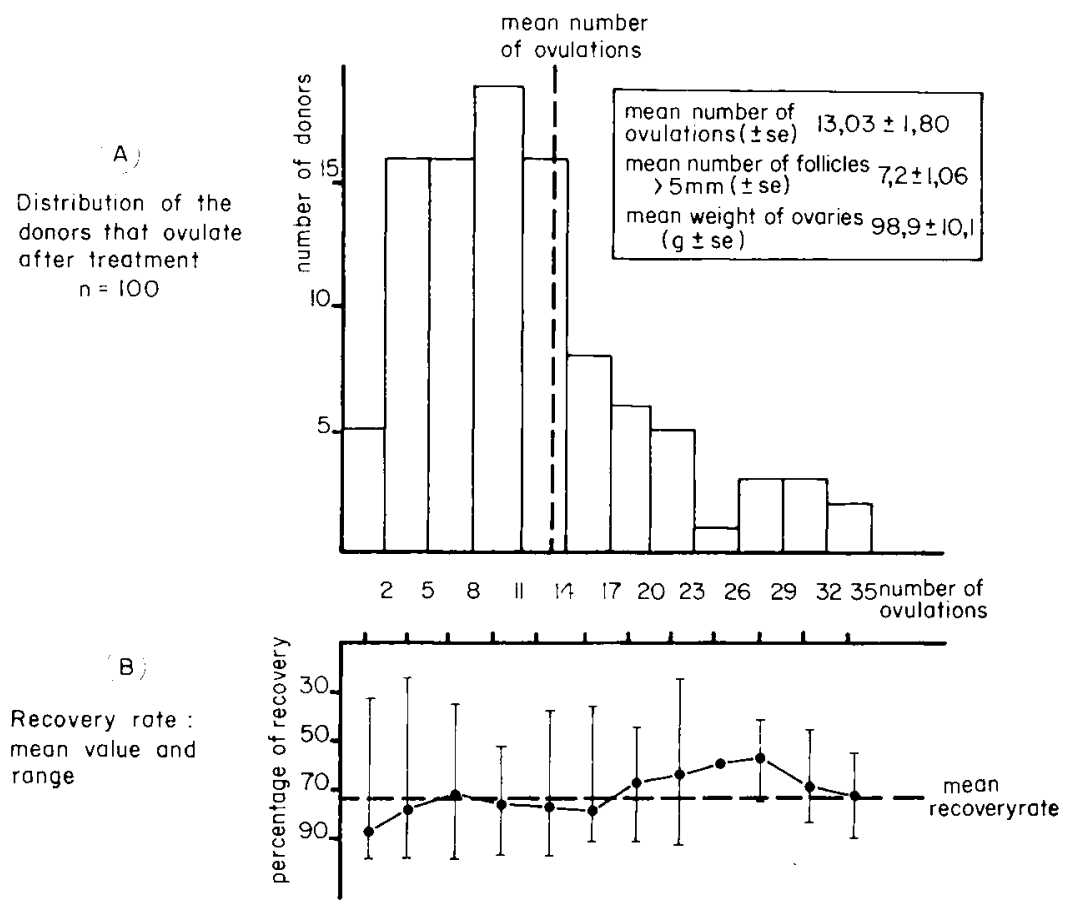

FIG. 1. - Distribution of donors and recovery rate of embryos according to the number of ovulations. 
Embryonic recovery rate varied from one animal to another. It was higher than or equal to 80 p. 100 for 42 females, but less than or equal to 40 p. 100 for 11 of them. Recovery rate did not depend on the number of ovulations. Figure 1 shows that it is practically constant between 3 and 35 ovulations. However, the percentage of females from which more than 80 p. 100 of the embryos were recovered tends to decrease as the number of ovulations increases. This percentage is 29.7 p. $100(11 / 37)$ when there are fewer than 10 ovulations, 25.7 p. $100(9 / 35)$ when the number of ovulations is between 10 and 15 ; it falls to 17.5 p. $100(5 / 28)$ when there are more than 15 ovulations.

\section{TABLE 1}

Ovulation rate and recovery of embryos 100 Charolais heifers given 2,100 UI PMSG and slaughtered from days 6 to 12

\begin{tabular}{|c|c|c|c|c|c|c|c|c|}
\hline Day of cycle at recovery & D 6 & D 7 & D 8 & D 9 & D 10 & D 11 & D 12 & Total \\
\hline Number of donors ...... & 16 & 17 & 16 & 13 & 15 & 10 & 13 & 100 \\
\hline $\begin{array}{l}\text { Mean number of ovula- } \\
\text { tions } \ldots \ldots \ldots \ldots \ldots \ldots \ldots \\
\text { (SE) } \ldots \ldots \ldots \ldots \ldots \ldots \ldots\end{array}$ & $\begin{array}{c}11,9 \\
(2,1)\end{array}$ & $\begin{array}{c}15,3 \\
(2,1)\end{array}$ & $\begin{array}{c}12,9 \\
(1,9)\end{array}$ & $\begin{array}{c}14,0 \\
(2,7)\end{array}$ & $\begin{array}{c}14,7 \\
(2,2)\end{array}$ & $\begin{array}{c}9,8 \\
(1,3)\end{array}$ & $\begin{array}{c}11,2 \\
(1,5)\end{array}$ & $\begin{array}{c}13,03 \\
(1,8)\end{array}$ \\
\hline $\begin{array}{l}\text { Mean number of collected } \\
\text { embryos } \ldots \ldots \ldots \ldots \ldots \\
\text { (SE) } \quad \ldots \ldots \ldots \ldots \ldots \ldots\end{array}$ & $\begin{array}{c}9,3 \\
(1,6)\end{array}$ & $\begin{array}{c}11,9 \\
(1,9)\end{array}$ & $\begin{array}{c}9,4 \\
(1,1)\end{array}$ & $\begin{array}{c}10,2 \\
(2,1)\end{array}$ & $\begin{array}{l}11,1 \\
(1,7)\end{array}$ & $\begin{array}{c}7,6 \\
(1,1)\end{array}$ & $\begin{array}{c}8,0 \\
(1,2)\end{array}$ & $\begin{array}{c}9,94 \\
(1,54)\end{array}$ \\
\hline Percentage of recovery ... & 78,1 & $\overline{77,2}$ & 72,8 & 72,8 & 75,4 & 77,5 & 71,4 & 76,2 \\
\hline
\end{tabular}

TABLE 2

Distribution of superovulated embryos according to their morphological aspect

\begin{tabular}{|c|c|c|c|c|c|c|c|}
\hline \multirow{2}{*}{ Collected embryos } & \multicolumn{7}{|c|}{ Days of cycle at recovery } \\
\hline & D 6 & D 7 & D 8 & D 9 & D 10 & D 11 & D 12 \\
\hline Total ................ & 149 & 185 & 151 & 132 & 197 & 76 & 104 \\
\hline $\begin{array}{l}\text { Abnormal } \ldots \ldots \ldots \ldots \ldots \ldots \\
(p .100) \ldots \ldots \ldots \ldots\end{array}$ & $\begin{array}{l}20 \\
(13,4)\end{array}$ & $\begin{array}{l}30 \\
(16,2)\end{array}$ & $\begin{array}{l}38 \\
(25,1)\end{array}$ & $\begin{array}{l}24 \\
(18,1)\end{array}$ & $\begin{array}{l}50 \\
(25,3)\end{array}$ & $\begin{array}{c}24 \\
(31,5)\end{array}$ & $\begin{array}{c}35 \\
(33,4)\end{array}$ \\
\hline $\begin{array}{l}6-12 c / \ldots \ldots \cdots \cdots \cdots \cdots \\
(p .100) \ldots \ldots \cdots \cdots\end{array}$ & $\begin{array}{l}24 \\
(16,1)\end{array}$ & $\begin{array}{l}8 \\
(4,3)\end{array}$ & - & - & - & - & - \\
\hline $\begin{array}{l}\text { Morula } 12-20 c / \ldots \ldots \ldots \ldots \\
(p .100) \ldots \ldots \ldots \ldots \ldots \ldots\end{array}$ & $\begin{array}{l}94 \\
(63,0)\end{array}$ & $\begin{array}{l}53 \\
(28,6)\end{array}$ & $\begin{array}{l}16 \\
(10,5)\end{array}$ & $\begin{array}{l}22 \\
(16,6)\end{array}$ & $\begin{array}{l}15 \\
(7,6)\end{array}$ & - & - \\
\hline $\begin{array}{l}\text { Young blastocyst } \ldots \ldots \ldots \\
\text { (p. 100) } \ldots \ldots \ldots \ldots \ldots\end{array}$ & $\begin{array}{l}11 \\
(7,3)\end{array}$ & $\begin{array}{l}71 \\
(38,3)\end{array}$ & $\begin{array}{l}19 \\
(12,5)\end{array}$ & $\begin{array}{c}17 \\
(12,8)\end{array}$ & $\begin{array}{l}9 \\
(6,3)\end{array}$ & - & - \\
\hline $\begin{array}{l}\text { Blastocyst } \ldots \ldots \ldots \ldots \ldots \ldots \\
(p .100) \ldots \ldots \ldots \ldots\end{array}$ & 一 & $\begin{array}{l}23 \\
(12,4)\end{array}$ & $\begin{array}{l}71 \\
(47,0)\end{array}$ & $\begin{array}{l}38 \\
(28,7)\end{array}$ & $\begin{array}{l}11 \\
(5,5)\end{array}$ & $\begin{array}{l}2 \\
(2,6)\end{array}$ & $\begin{array}{l}2 \\
(1,9)\end{array}$ \\
\hline $\begin{array}{l}\text { Hatched blastocyst ........ } \\
(p .100) \ldots \ldots \ldots \ldots \ldots \ldots\end{array}$ & - & - & $\begin{array}{l}7 \\
(4,6)\end{array}$ & $\begin{array}{c}31 \\
(23,4)\end{array}$ & $\begin{array}{l}112 \\
(56,8)\end{array}$ & $\begin{array}{c}50 \\
(65,7)\end{array}$ & $\begin{array}{l}67 \\
(64,4)\end{array}$ \\
\hline
\end{tabular}


Embryonic recovery rate did not vary with the day of recovery between D 6 and D 12 ; it is between 71.4 and 78.1 p. 100 (table 1) for lots of animals of comparable size (10 to 17 females) and not having a significantly different mean number of ovulations $(P<0.05)$. We recovered, per donor and depending on the day of recovery, a mean of 7.6 to 11.9 embryos.

3. Morphological aspect of recovered embryos. - Table 2 shows embryo distribution according to morphological aspect for each day of recovery. Whatever the day of recovery, the embryos fall into several classes defined by morphological criteria : from $D 6$ to $D 10$ they are distributed into at least 4 classes ; on the contrary, at D 11 and D 12 more than 95 p. 100 of them fall into only two classes.

4. Embryo viability. - After in vitro culture of the embryos recovered at D 6 (table 3.A), 65 p. 100 of the morulae develop as against only 5.5 p. 100 of 8 to 12-cell embryos. At D 7, 74 p. 100 of the early blastocysts develop as against 26 p. 100 of the morulae. At D 8 and D 9, the rate of blastocyst development is 66 and 61.5 p. 100 , respectively, as against 25 and 16 p. 100 for the embryos in the preceding category (early blastocyst).

At D 10, D 11 and D 12 (table 3.B), 80 p. 100 of the embryos hatched from the zona pellucida increase in size in vitro in $24 \mathrm{hrs}$.

TABLE 3

In vitro development of superovulated embryos collected from day 6 to dat 12 of the cycle

A. Number of embryos (and percentage) hatching from the zona

\begin{tabular}{|c|c|c|c|c|c|}
\hline $\begin{array}{l}\text { Day of } \\
\text { recovery }\end{array}$ & $\begin{array}{l}\text { Length of } \\
\text { culture } \\
\text { (hrs) }\end{array}$ & $\begin{array}{l}\text { Morphological } \\
\text { aspect of embryos } \\
\text { before culture }\end{array}$ & $\begin{array}{l}\text { Numver } \\
\text { of } \\
\text { embryos }\end{array}$ & devel & $\begin{array}{l}\text { er of } \\
\text { embryos } \\
\text { 00) }\end{array}$ \\
\hline D 6 & 96 & $\begin{array}{l}6-12 \mathrm{c} / \ldots \ldots \ldots \ldots \ldots \ldots \ldots \\
\text { morula } \ldots \ldots \ldots \ldots \ldots \ldots \ldots\end{array}$ & $\begin{array}{l}18 \\
20\end{array}$ & $\begin{array}{r}1 \\
13\end{array}$ & $\begin{array}{r}(5,5) \\
(65,0)\end{array}$ \\
\hline D 7 & 72 & $\underset{\text { young blastocyst }}{\operatorname{morula}} \ldots \ldots \ldots \ldots$ & $\begin{array}{l}23 \\
19\end{array}$ & $\begin{array}{r}6 \\
14\end{array}$ & $\begin{array}{l}(26,0) \\
(74,0)\end{array}$ \\
\hline D 8 & 48 & $\begin{array}{l}\text { morula } \ldots \ldots \ldots \ldots \ldots \ldots \ldots \ldots \\
\text { young blastocyst. } \ldots \ldots \ldots \ldots \ldots \\
\text { blastocyts. } \ldots \ldots \ldots \ldots \ldots \ldots \ldots\end{array}$ & $\begin{array}{l}12 \\
24 \\
15\end{array}$ & $\begin{array}{r}1 \\
6 \\
10\end{array}$ & $\begin{array}{r}(8,3) \\
(25,0) \\
(66,0)\end{array}$ \\
\hline D 9 & 24 & $\begin{array}{l}\text { young blastocyst } \ldots \ldots \ldots \ldots \ldots \\
\text { blastocyst } \ldots \ldots \ldots \ldots \ldots \ldots\end{array}$ & $\begin{array}{r}6 \\
13\end{array}$ & $\begin{array}{l}1 \\
8\end{array}$ & $\begin{array}{l}(16,0) \\
(61,5)\end{array}$ \\
\hline D 10 & 24 & blastocyst $\ldots \ldots \ldots \ldots \ldots \ldots$ & 28 & 11 & $(39,2)$ \\
\hline
\end{tabular}

B. Number of embryos (and percentage) with an increase of size after $24 \mathrm{hrs}$ of culture

\begin{tabular}{ccccc}
\hline $\begin{array}{c}\text { Day of } \\
\text { recovery }\end{array}$ & $\begin{array}{c}\text { Number of developed embryos } \\
(\mathrm{p} .100)\end{array}$ & $\begin{array}{c}\text { Mean size ( } \mu \pm \text { SE) before } \\
\text { and after culture }\end{array}$ \\
\hline D 10 & $21 / 26$ & $(80,7)$ & $193,6 \pm 37,2$ & $215,5 \pm 43,8$ \\
D 11 & $6 / 7$ & $(85,7)$ & $263,2 \pm 63,0$ & $406,6 \pm 108,5$ \\
D 12 & $17 / 21$ & $(80,9)$ & $416,5 \pm 65,2$ & $650,4 \pm 90,0$ \\
\hline
\end{tabular}


It is logical to assume that the class of embryos in which more than 60 p. 100 developed in vitro, corresponded to the normal stage of development for a given day of recovery, and that the embryos in the preceding class presented a retarded development since their evolution in vitro was less than $30 \mathrm{p}$. 100. The following were considered as normal embryos: D 6 morulae, early D 7 blastocysts, D 8 and D 9 blastocysts, blastocysts hatched from the zona pellucida at D 10, D 11, D 12. The following were assessed as retarded : 8 to 12-cell embryos at D 6, D 7 morulae, early D 8 and D 9 blastocysts and blastocysts in the zona pellucida at D 10, D 11, D 12.

Embryos with no apparent structure showed practically no development in vitro whatever the day of recovery. These embryos were degenerate.

The ability to hatch from the zona pellucida or to increase in size in vitro thus permitted the embryos, characterized by the preceding morphological criteria, to be divided into three different classes of viability (table 4). For a given day of recovery, normal, retarded and degenerate embryos may be distinguished.

\section{TABLE 4}

Morphological aspect viability of embryos at different days of the cycle at recovery

\begin{tabular}{|c|c|c|c|c|}
\hline $\begin{array}{l}\text { Day of the } \\
\text { cycle at } \\
\text { recovery }\end{array}$ & $\begin{array}{l}\text { Normal } \\
\text { embryos }\end{array}$ & $\begin{array}{l}\text { Retarded } \\
\text { embryos }\end{array}$ & Degenerat & d embryos \\
\hline D 6 & morula & $6-12 c /$ & \multirow{3}{*}{\multicolumn{2}{|c|}{ 6-12c/ $\quad \begin{array}{c}\text { mon } \\
\text { mortilized } \\
\text { and } \\
\begin{array}{c}\text { disorganized } \\
\text { embryos }\end{array}\end{array}$}} \\
\hline D 7 & $\begin{array}{l}\text { young } \\
\text { blastocyst }\end{array}$ & morula & & \\
\hline $\begin{array}{l}\text { D } 8 \\
\text { D } 9\end{array}$ & blastocyst & $\begin{array}{l}\text { young } \\
\text { blastocyst }\end{array}$ & & \\
\hline $\begin{array}{l}\text { D } 10 \\
\text { D } 11 \\
\text { D } 12\end{array}$ & $\begin{array}{l}\text { hatched } \\
\text { blastocyst }\end{array}$ & blastocyst & $\begin{array}{l}\text { young } \\
\text { blastocyst }\end{array}$ & \\
\hline
\end{tabular}

5. Percentage of normal, retarded and degenerate embryos at different days of recovery. - The percentage of normal embryos (fig. 2) decreases from D 6 to D 7 (70.4 as against 50.8 p. 100 ; significant difference : $P<0.01$ ). During the following days of recovery, it progresses little until D 10. Curiously, with the morphological criteria we used, it tends to increase until D 11 and $D 12$ (69.7 and 64.4 p. 100, respectively).

The percentage of retarded embryos increases from $D 6$ to $D 7$ (16.1 as against 28.6 p. 100 ; significant difference : $P<0.05)$. It decreases from $D 7$ to $D 8$ (28.6 as against 12.6 p. 100 ; significant difference : $P<0.01$ ) and at the following recovery stages (at D 10, retarded embryos represent only 6.5 p. 100 of the recovered embryos). They are not found any more at D 11 and D 12 .

The percentage of degenerate embryos increases from $D 7$ to $D 8$ (20.5 as against 35.7 p. 100 ; significant difference : $P<0.01$ ). It remains constant during the following recovery days until D 12 when it represents 33.6 p. 100 of the recovered embryos. 


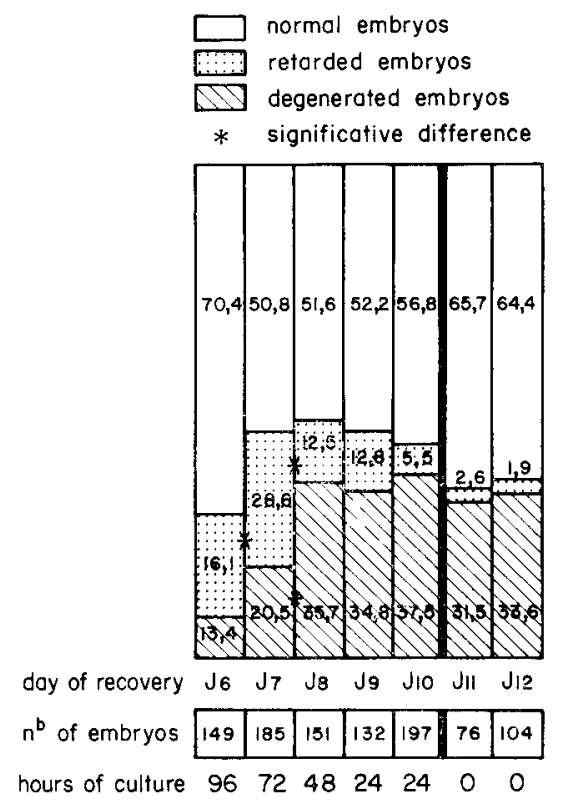

FIG. 2. - Percentages of normal, retarded and degenerated embryos at different days of recovery.

6. Donor variability. - For the same number of ovulations, the distribution of the embryos according to their quality varied greatly from one donor to another. The percentage of normal embryos might vary from 0 to 100 p. 100 in 2 females recovered the same day and having the same number of ovulations.

The number of normal, retarded and degenerate embryos could not be exactly predicted for a given animal. Figure 3 shows that the proportion of females with more than 50 p. 100 of degenerate embryos tends to increase from $D 6$ to $D 12$, while at the same time, the proportion of females with more than 50 p. 100 of retarded embryos falls to 0 at $D 9$. The probability of obtaining a greater number of degenerate embryos tends to be higher at late recovery stages (D 11 and D 12). But, whatever the stage of recovery, the proportion of females with more than 50 p. 100 of normal embryos does not vary significantly.

FIG. 3. - Percentage of superovulated heifers with more than 50 p. 100 retarded embryos (dotted lines) or degenerated embryos (plain lines). Mean percenlage and confidence embryos (plain lines). Mean percentage and confidence limit for $P=0,05$ (number of animals).

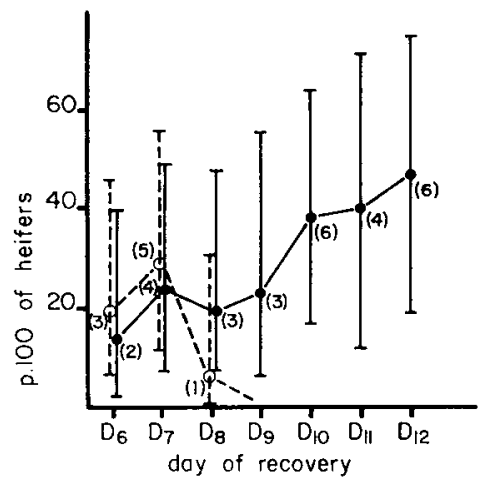




\section{Discussion.}

Quantitative ovarian response to this superovulation treatment was satisfactory (a mean of $13.03 \pm 1.8$ ovulations), but the variability of the response (from 0 to 35 ovulations) was very wide and of the same order as that observed by other authors on animals of a different breed (Sreenan and Beehan. 1976 ; Brand et al., 1978). Two simple criteria-hatching from the zona pellucida and increase in blastocyst diameter in vitro - permitted us to distinguish, for a given day of recovery, groups of embryos having different potentialities for development in vitro.

The categories corresponding to embryos classed as normal (according to the criterion of hatching from the zona pellucida) were considered as containing viable embryos. At D 8, these embryos had a morphological aspect similar to that described by Chang (1952) for embryos produced after natural ovulation. This was also true at $D 6$ for superovulated embryos assessed as normal when composed of about 32 cells at the morula stage (Trounson, Willadsen and Rowson, 1976), and at D 7 when they reached the blastocyst stage (Newcomb, Rowson and Trounson, 1976). At these days of recovery, more than 91 p. 100 of the embryos judged normal could develop in vivo after transplantation (Rowson ef al., 1972). However, culture in vitro itself may not, at present, be used for selecting the embryos.

After culture in vitro and although hatching from the zona pellucida may be related to a natural embryonic activity (Fléchon and Renard, 1978), the viability of embryos assessed as normal, decreased. After recovery at D 6 and D 7 and culture for 96 and $72 \mathrm{hrs}$, only two embryos out of 11 (18.1 p. 100) developed in vivo after cervical transfer (Renard, unpublished data). For shorter-term cultures ( $48 \mathrm{hrs}$ ), viability also decreased although survival rate after surgical transfer remained high (50 p. 100 ; Trounson ef al., 1976).

The criterion used at D 10 and later (increase in the size of the blastocysts in vitro) was insufficient for defining a category of viable embryos. After recovery at D 10 to D 12, morphologically identical embryos developing in the same way in vitro might have a different metabolism. However, this metabolism, measured by the glucose uptake of each embryo, was related to viability in vivo (Renard, Philippon and Ménézo, 1980). It is thus necessary to define other criteria for a more precise selection of the embryos. At D 7, the percentage of normal embryos was significantly lower than at D 6 (50 p. 100 as against 70 p. 100). At the same time, the percentage of retarded embryos increased ( 28 vs. 20 p. 100). This evolution occurred at the time of blastocyst formation and it could be that the transition from morula to blastocyst corresponded to a critical stage of development in vitro after superovulation in the cow.

Only 26 p. 100 of the retarded embryos at the morula stage at D 7 developed in vitro. This result is analogous to the one obtained by Trounson ef al. (1976) for the same day of recovery.

At D 8, the percentage of degenerate embryos increased ( 35 vs, 20 p. 100 at D 7). This corresponds to the observations of Newcomb ef al., 1976) who believed this increase in the percentage of degenerate embryos was due to an unfavorable endocrine environment and to the premature entrance of eggs in the uterus. Our results show that these degenerations observed at D 8 are the consequence of the retarded 
development of a part of the embryos at D 7 when the blastocyst is forming. At this stage of embryonic development, several authors have emphasized the effect of the hormonal medium in vivo (mouse : Kirby, 1962 ; rat : Dickmann, 1970 ; ewe : Wintenberger-Torres, 1964) or in vitro (mouse : Kirpatrick, 1971 ; Whitten, 1957). However, in the cow, the endocrine factor does not entirely explain the degenerations we observed. The percentage of normal embryos, varying between 0 and 100 p. 100 depending on the donors, was unrelated to plasma $E_{2} 17 \beta$ and progesterone concentrations which were measured by plasma assay after daily sampling from the PMSG injection until recovery (Renard et al., 1978).

After D 8, the percentage of embryos classed as « retarded 》, diminished progressively so that at D 11 and D 12 practically no more embryos were found. Eldsen et al. (1978) showed that between D 6 and D 9 some embryos presenting a slightly retarded development had low, but not zero, viability after transfer (18 vs. 61 p. 100 for normal embryos). A part of the embryos classed as « retarded » might have evolved towards the class of degenerate embryos. This could explain the progressive disappearance of retarded embryos at D 12 as well as the augmentation in the percentage of normal embryos which we found between D 10 and D 12.

\section{Conclusion.}

In vitro culture permits the definition of morphological criteria for the selection of superovulated embryos on their viability at a given day of recovery. From D 6 to D 10, hatching from the zona pellucida, which is an easily visuable in vitro modification would permit assessmet of viability for embryos submitted to different manipulations. Beyond D 10, it is difficult to estimate embryonic viability using only morphological criteria. Normal embryos should be selected by other means as for example measurements of metabolism in vitro.

EEC Seminar on «Ovarian stimulation and egg quality in mammals », Luynes, France, octobre 1978,

Acknowledgment. - We are grateful to Viviane Garnier, Marie-Claire Théron and Patrick Chesné for skillfull technical assistance, to Aline Solari for statistical analysis, and to Marie-Claire Levasseur for reading and criticizing the manuscript. - This work was supported by EEC Coordination for Agricultural Research.

Résumé. Les relations entre l'aspect morphologique des embryons bovins produits après superovulation et leur développement in vitro permettent de définir des critères de qualité de ces embryons. L'observation de 994 embryons produits par 100 donneuses superovulées montre que pour chaque jour de collecte de J 6 à J 10 les embryons peuvent être répartis selon leur aspect morphologique dans au moins 4 classes. A J 11 et J 12, plus de 95 p. 100 des embryons sont répartis dans deux classes seulement : embryons anormaux ef blastocystes sortis de la zone pellucide.

- S'ils sont dans la zone pellucide, le jour de la collecte, plus de 60 p. 100 des embryons morphologiquement normaux sortent de leur zone pellucide après culture in vitro. Par contre moins de 26 p. 100 des embryons morphologiquement retardés se libèrent de leur zone pellucide in vitro et aucun embryon classé dégénéré selon nos critères, ne se développe. 
- Pour les embryons déjà sortis de la zone pellucide au moment de la collecte, 80 p. 100 des embryons présentent une augmentation de taille après $24 \mathrm{~h}$ de culture in vitro.

Le pourcentage d'embryons normaux diminue de $\mathrm{J} 6$ à $\mathrm{J} 7$ puis reste stable au moins jusqu'à $\mathrm{J} 10$. Le pourcentage d'embryons retardés augmente de $\mathrm{J} 6$ à $\mathrm{J} 7$ puis décroît ensuite. La proportion d'embryons retardés est très faible à $\mathrm{J} 11$ ef $\mathrm{J} 12$. Le pourcentage d'embryons dégénérés augmente de $\mathrm{J} 7$ à 78 puis reste stable. La proportion des donneuses dont plus de 50 p. 100 des embryons sont dégénérés, augmente entre $J 6$ et J 12. La relation avec l'aptitude au développement in vivo après transplantation est discutée.

\section{References}

BETTERIDGE K. J., 1977. Embryo transfer in farm animals. Canada Dept of Agriculture, Monograph $n^{\circ} 16,2$.

BRAND A., AARTS M. H., ZAAYER D., OXENDER W. D., 1978. Recovery and transfer of embryos by non surgical procedures in lactating dairy cattle, 281-291. In SREENAN J. M. Control of reproduction in the cow. CEC, Martinus Nighoff, The Hague.

CHANG M. C., 1952. Development of bovine blastocyst with a note on implantation. Anat. Rec., 113, $143-161$.

DICKMANN Z., 1970. Effects of progesterone on the development of the rat morula. Fertil. Steril., 21, 541-548.

ELDSEN R. P., NELSON L. D., SEIDEL J. R., 1978. Superovulating cows with FSH and PMSG. Theriogenology, 9, 17-26.

FLÉCHON J. E., RENARD J. P., 1978. A scanning electron microscope study of the hatching of bovine blastocyst in vitro. J. Reprod. Fert., 59, 9-12.

KIRBY DR. S., 1962. The effects of the uterine environment on the development of mouse eggs. J. Embryol. exp. Morphol., 20, 496.

KIRKPATRICK J. F., 1971. Differential sensitivity of preimplantation mouse embryos in vitro to cestradiol and progesterone. J. Reprod. Fertil., 27, 283-286.

NEWCOMB R., ROWSON L. E. A., TROUNSON A. O., 1976. The entry of superovulated eggs into the uterus, 1-15. In ROWSON L. E. A. Egg transfer in cattle, CEC Luxembourg Eur. 5491.

RENARD J. P., DU MESNIL du BUISSON F., WINTENBERGER-TORRES S., MÉNÉZO Y., 1976. In vitro culture of cow embryos frcm day 6 and day 7, 159-164. In RO WSON L. E. A. Egg transfer in cattle, CEC, Luxembourg Eur. 5491.

RENARD J. P. MÉNÉZO Y., SAUMANDE J., HEYMAN Y., 1978. Attemps to predict the viability of cattle embryos produced by superovulation, 398-417. In SREEMAN J. M. Confrol of reproduction in the cow. CEC, Martinus Nighoff, The Hague.

RENARD J. P., PHILIPPON A., MÉNÉZO Y., 1980. In vitro uptake of glucose by bovine blastocyst : a study for egg transfer. J, Reprod. Fertil., 58 (in press).

ROWSON L. E. A., LAWSON R. A. S., MOOR R. M., BAKER A. A., 1972. Egg transfer in the cow : synchronization requirements. J. Reprod. Fertil., 28, 427-431.

SHEA B. F., HINES D. J., LIGHTFOOT D. E., OLLIS G. W., OLSON S. M., 1976. The transfer of bovine embryos, 145-152. In ROWSON L. E. A. Egg transfer in cattle, CEC Luxembourg, Eur. 5491.

SREENAN J. M., BEEHAN D., 1976. Methods of induction of superovulation in the cow and transfer results, 19-24. In ROWSON L. E. A. Egg transfer in cattle, CEC, Luxembourg, Eur. 5491.

TROUNSON A. O., WILLADSEN S. M., ROWSON L. E. A., 1976. The influence of in vitro culture and cooling on the survival and development of cow embryos. J. Reprod. Fertil., 47, 367-370.

WHITTEN W. K., 1957. The effect of progesterone on the development of mouse eggs in vitro. J. Endocrinol., 16, 80-85.

WHITTINGHAM D. G., 1971. Survival of mouse embryos after freezing and thawing. Nature (London), 233, 125.

WINTENBERGER-TORRES S., 1964. Influence de l'équilibre hormonal sur la vitesse de segmentation des œufs de brebis. C. R. Acad. Sci., Paris, 259, 1660-1662. 